\title{
PREVALENSI Vibrio parahaemolyticus PADA UDANG VANAME DI UNIT PENGOLAHAN IKAN JAWA TENGAH DAN JAWA TIMUR
}

\section{Prevalence of Vibrio parahaemolyticus in Whiteleg Shrimp at Fish Processing Units in Central Java and East Java}

\author{
Arifah Kusmarwati ${ }^{\star}$, Fairdiana Andayani, dan Yusma Yennie \\ Balai Besar Riset Pengolahan Produk dan Bioteknologi Kelautan dan Perikanan, \\ JI. KS Tubun, Petamburan VI, Slipi, Jakarta Pusat, Indonesia \\ *Korespondensi Penulis: arifah.kusmarwati@kkp.go.id \\ Diterima: 29 November 2019; Direvisi: 21 Januari 2020; Disetujui: 1 Mei 2020
}

\begin{abstract}
ABSTRAK
Vibrio parahaemolyticus patogen selain membahayakan kesehatan manusia juga menjadi alasan penolakan ekspor udang di beberapa negara. Penelitian ini dilakukan untuk mengisolasi, mengidentifikasi dan mengkuantifikasi keberadaan V. parahaemolyticus patogen pada udang vaname (Litopenaeus vannamei) di Unit Pengolahan Ikan (UPI) Jawa Tengah dan Jawa Timur. Pengambilan sampel udang vaname dilakukan secara tertelusur di sepanjang rantai pasok pengolahan udang menggunakan metode acak purposif. Sampel udang yang diambil berukuran 20-48 g/ekor (size 21-51). Sebanyak 10 unit sampel dengan berat masing-masing 400-500 g diambil dari setiap tambak udang intensif. Dengan berat yang sama, sebanyak 10-30 sampel diambil dari setiap tahapan pengolahan udang di UPI secara tertelusur. Identifikasi $V$. parahaemolyticus merujuk pada metode SNI 01-2332.5-2006 dan PCR dengan gen penyandi spesifik tox $R$, tdh dan trh. Prevalensi $V$. parahaemolyticus dari total sampel udang yang berasal dari tambak dan UPI Jawa Tengah adalah 17 dari 50 (34\%) sampel, di mana empat (4) sampel positif mengandung gen $t d h$ dan tiga (3) sampel positif mengandung gen trh. Sedangkan prevalensi $V$. parahaemolyticus dari sampel yang berasal dari Jawa Timur sebesar 29 dari $60(48,33 \%)$ sampel positif PCR, dan tidak terdeteksi $V$. parahaemolyticus patogen. Oleh karena itu sangat penting dilakukan upaya perbaikan penanganan udang paska panen, khususnya di UPI Jawa Tengah terutama pada titik kritis proses pengolahannya.
\end{abstract}

KATA KUNCI : bakteri patogen, prevalensi, udang, Vibrio parahaemolyticus

\section{ABSTRACT}

Apart from being a major cause of foodborne disease in human, pathogenic Vibrio parahaemolyticus also becomes the main reason for shrimp export rejection in several countries. This study was carried out to isolate, identify and quantify the prevalence of pathogenic $\underline{\mathrm{V}}$. parahaemolyticus in whiteleg shrimp (Litopenaeus vannamei). Shrimp with size of 21-51 (20-48 g/shrimp) from ponds and fish processing units in Central and East Java were used in this study. Ten sample units of 400-500 g shrimp were collected from each intensive pond, while 10-30 sample units (400-500 g) were collected from each processing step in the fish processing units. Pathogenic $\underline{V}$. parahaemolyticus was identified using PCR with specific coding gen (toxR, tdh and trh) and method recommended by SNI 01-2332.5-2006. The prevalence of $V$. parahaemolyticus in shrimp from Central Java was 17 out of 50 (34\%) samples. Amongst these, four (4) were positive tdh and three (3) were positive trh. For sample from East Java, $\underline{V}$. parahaemolyticus was found 29 out of $60(48.33 \%)$ and no pathogenic $V$. parahaemolyticus was detected. To avoid future contamination of $\underline{V}$. parahaemolyticus, post-harvest handling of shrimp especially in the processing units in Central Java should be improved.

KEYWORDS: pathogenic bacteria, prevalence, shrimp, Vibrio parahaemolyticus 


\section{PENDAHULUAN}

Kontribusi devisa dari komoditas udang bagi Indonesia sebesar 136,3 ribu ton yang setara dengan US $\$ 1,13$ miliar telah menyebabkan kenaikan volume ekspor udang hingga 6,84\% dengan nilai ekspor sebesar 3,75 (Mo, 2017). Volume ekspor udang yang terbesar adalah ke Amerika Serikat senilai US\$ 938 juta (Katadata KKP, 2016) yang sebagian besar berasal dari tambak udang intensif di Pantai Utara Jawa.

Ekspor udang beku vaname asal Indonesia untuk pasar Italia dan Uni Eropa pada tahun 2005-2009 dan 2016 mengalami penolakan karena terdeteksi adanya V. parahemolyticus, selanjutnya di tahun 2009 dan 2010 terjadi penolakan ekspor ikan dan produk perikanan oleh Cina dan Taiwan akibat adanya kontaminasi bakteri $V$. parahaemolyticus (Ditjen P2HP-KKP, 2010; RASFF, 2019; Sunorita \& Tjarsono, 2014).

Vibrio parahaemolyticus adalah bakteri motil, Gram negatif dan bersifat halofilik yang secara alami sering dijumpai di perairan payau, pantai dan laut (Ceccarelli, Hasan, Huq, \& Colwell, 2013; Wang et al., 2015; Zhang \& Orth, 2013). Secara normal V. parahaemolyticus berada pada produk-produk perikanan, termasuk ikan, udang dan kerang, sehingga kasus keracunan pangan akibat bakteri ini berasosiasi dengan konsumsi berbagai jenis produk perikanan. Konsumsi produk perikanan mentah ataupun setengah matang bahkan produk matang namun telah terkontaminasi $V$. parahaemolyticus dapat menyebabkan infeksi yang dosisnya berkisar antara $10^{5}-10^{7} \mathrm{cfu} / \mathrm{g}$ (Centre for Health Protection, 2010). Sementara itu, Raghunath (2015) dan Chen, Hasan dan Huq (2017) menyebutkan bakteri ini merupakan salah satu penyebab utama penyakit gastroenteritis di dunia, terutama yang berasosiasi dengan konsumsi produk perikanan mentah atau setengah matang.

Tidak semua V. parahaemolyticus adalah patogen, sehingga $V$. parahaemolyticus yang dapat menyebabkan penyakit pada manusia adalah yang mengandung toksin thd atau trh yang diekspresikan dalam bentuk lisisnya sel darah merah pada agar Wagatsuma. Mekanisme ini dikenal sebagai fenomena Kanagawa positif yang menunjukkan adanya toksin yang dihasilkan oleh gen tdh. $V$. parahaemolyticus yang diisolasi dari lingkungan tanpa kedua gen tersebut juga menunjukkan sifat sitotoksis pada manusia (Broberg, Caldern \& Orth, 2011; Nishibuchi \& Kaper, 1995; Raghnunath, 2015). Namun, sekitar $10 \%$ strain klinis tidak memiliki gen tdh atau trh.
Berdasarkan hasil isolasi sampel swab rektum pasien yang menderita diare serupa kolera yang terjadi di Indonesia antara tahun 1996-1998 terdeteksi adanya V. Cholerae $\mathrm{O} 1$ dan V. parahaemolyticus (Lesmana et al., 2001; Lesmana et al., 2002). Infeksi atau wabah bahkan pandemi di negara lain yang disebabkan $V$. parahaemolyticus pernah dilaporkan terjadi di Australia tahun 1990 dan 1992, Thailand dan Taiwan pada tahun 1986-2001, India dan Amerika Serikat pada tahun 1996, Malaysia tahun 2002-2004 serta beberapa negara Asia lainnya (Kraa, 1995; Matsumoto et al., 2000; Nelapati \& Krishnaiah, 2010; Okuda et al., 1997; Sani, Ariyawansa, Babji, \& Hashim, 2013). Oleh karena kajian prevalensi $V$. parahaemolyticus pada produk perikanan hasil budidaya atau hasil tangkapan di Indonesia masih sangat terbatas (Amizar, 2011; Widowati, 2008), penelitian untuk mendukung kajian tersebut menjadi sangat diperlukan, yang nantinya akan digunakan sebagai masukan untuk mendukung kebijakan ekspor produk udang dari Indonesia.

\section{BAHAN DAN METODE}

\section{Bahan}

Bahan utama yang digunakan pada penelitian ini adalah udang vaname (Litopenaeus vannamei) berukuran 20-48 g/ekor (size 21-51) yang berumur 5382 hari. Penentuan lokasi Unit Pengolahan Ikan (UPI) didasarkan pada daftar UPI terbesar di Kabupaten Pati (Jawa Tengah) dan Banyuwangi (Jawa Timur) yang direkomendasi oleh Badan Karantina Ikan, Pengendalian Mutu, dan Keamanan Hasil Perikanan (BKIPM) Jakarta, sementara lokasi tambak ditentukan oleh masing-masing UPI. Empat tambak udang intensif yang dipilih merupakan penyedia bahan baku untuk masing-masing UPI yang memiliki 16 hingga 22 petak tambak dengan luasan setiap petak berukuran $4000 \mathrm{~m}^{2}$. Pengambilan sampel dilakukan di tambak udang yang berlokasi di Desa Punjul Harjo, Kabupaten Rembang; Desa Sekuro, Kabupaten Jepara; Desa Wongsorejo, Kabupaten Banyuwangi; dan Desa Besuki, Kabupaten Situbondo. Tiga tambak yang berlokasi di Rembang, Jepara dan Banyuwangi merupakan tambak milik pemasok yang masingmasing menyediakan udang bagi tiga UPI, yaitu dua UPI di Jawa Tengah dan satu UPI di Jawa Timur. Sedangkan tambak yang berlokasi di Situbondo merupakan tambak milik perusahaan (UPI). Pengambilan sampel dilakukan secara tertelusur mulai dari tambak, penerimaan bahan baku di UPI, produk antara di UPI, serta produk akhir. 


\section{Metode}

\section{Pengambilan sampel}

Pengambilan sampel udang pada setiap lokasi dilakukan sebanyak satu kali mengikuti masa panen petani tambak yang diinfomasikan oleh unit BKIPM setempat. Sampel udang yang berasal dari tambak dan UPI di wilayah Jawa Tengah diambil pada bulan Mei, sementara yang berasal dari Jawa Timur diambil pada bulan September tahun 2016.

Pada setiap petakan tambak, sampel udang diambil dari lima titik. Pengambilan sampel di tambak Jawa Tengah dilakukan pada siang hari (12.30-16.00 WIB) dan tambak Jawa Timur pada pagi (04.00-05.30 WIB) dan sore hari (16.30-18.00 WIB). Kemudian seluruh sampel dari lima titik tersebut dikomposit menjadi satu unit sampel seberat 400-500 g. Pada setiap UPI, sampel udang diambil dari setiap tahap proses pengolahan yang berlangsung di UPI, dalam bentuk bahan baku, produk antara dan produk akhir. Sampel udang dari setiap tahap pengolahan diambil masing-masing lima titik pada pagi hingga sore hari (07.00-16.00 WIB). Seluruh sampel baik yang berasal dari tambak maupun UPI disampling secara aseptis mengikuti metode acak purposif dan dibekukan sebelum ditransportasikan ke Laboratorium Mikrobiologi Balai Besar Riset Pengolahan Produk dan Bioteknologi Kelautan dan Perikanan, Jakarta untuk selanjutnya dilakukan analisis.

\section{Isolasi dan seleksi V. parahaemolyticus dengan CHROMagar Vibrio (CV)}

Penelitian ini menggunakan metode analisis kualitatif dan kuantitatif secara paralel. Pengujian ada tidaknya $V$. parahaemolyticus dilakukan secara molekuler yang sebelumnya dilakukan tahap pengayaan bakteri dan seleksi dengan CHROMagar Vibrio (CV) (CHROMagar Microbiology, Paris, France) (Tarr et al. 2007). Proses isolasi dan seleksi dilakukan menurut Kusmarwati, Hermana, Yennie, dan Wibowo (2016). Sementara perhitungan konsentrasi bakteri secara kuantitatif dilakukan dengan metode Angka Paling Memungkinkan (APM) (USFDA, 2015).

CV merupakan media kromogenik yang membedakan 4 jenis Vibrio, yaitu $V$. parahaemolyticus, $V$. vulnivicus, $V$. cholera dan $V$. alginolyticus. Media ini merupakan media selektif untuk Vibrio karena memberikan hasil identifikasi visual yang baik untuk $V$. parahaemolyticus, $V$. vulnivicus, dan $V$. cholera dibandingkan media Thiosulfate Citrate Bile Salt Sucrose (TCBS, Oxoid, England). Penampakan koloni $V$. cholera dan $V$. vulnivicus pada media CV agar berwarna hijau biru, koloni V. parahaemolyticus violet/ungu kemerahan, dan V. alginolyticus tidak berwarna (Elhadi, 2012).

\section{Identifikasi V. parahaemolyticus patogenik}

Identifikasi $V$. parahaemolyticus yang meliputi reaksi PCR, amplifikasi dan elektroforesis mengacu pada Kusmarwati, et al. (2016); Yennie, Dewanti dan Poernomo (2015) dan Zulkifli et al. (2009), menggunakan primer gen toxR, tdh dan trh (Kim et al., 1999; Tada et al., 1992).

Elektroforesis dilakukan menggunakan gel agarose (Vivantis, Malaysia) 2\% dan bufer Tris Boric Acid EDTA (TBE, Thermo Scientific, USA) yang dilanjutkan dengan pewarnaan menggunakan etidium bromide $0,5 \mu \mathrm{g} / \mathrm{ml}$ (Thermo Scientific, USA). Identifikasi menggunakan kontrol positif $V$. parahaemolyticus ATCC 17802 (Remel, Europe, Ltd UK).

\section{HASIL DAN PEMBAHASAN}

\section{Lokasi sampling dan parameter fisiko kimia}

Empat perusahaan (UPI) yang menjadi lokasi penelitian adalah perusahaan pengekspor udang terbesar di wilayah Jawa Tengah dan Jawa Timur. Sebanyak 110 sampel dari tambak dan UPI tersebut diambil secara tertelusur mengikuti rantai pasok pengolahan udang di UPI mulai dari tambak, bahan baku di UPI, produk antara di UPI, dan produk akhir (Tabel 1).

Negara tujuan ekspor dari perusahaan-perusahaan tersebut meliputi Jepang, Amerika Serikat, dan sebagian Eropa. Sebagian besar perusahaan memperoleh bahan baku udang dari pemasok, namun terdapat perusahaan yang bahan bakunya berasal dari tambak milik perusahaan sendiri.

Hasil analisis fisiko kimia (temperatur dan $\mathrm{pH}$ air) perairan tambak udang (Tabel 2) menunjukkan bahwa di wilayah Jawa Tengah suhu air relatif tinggi dan mendekati suhu optimum untuk pertumbuhan bakteri V. parahaemolyticus $\left(37^{\circ} \mathrm{C}\right)$. Sementara di Jawa Timur suhu air tambak berkisar antara $25,0-30,3^{\circ} \mathrm{C}$ dengan kisaran $\mathrm{pH}$ 7,2-9,6.

Parameter fisiko kimia seperti suhu dan $\mathrm{pH}$ memiliki pengaruh secara langsung terhadap bakteri alami perairan seperti $V$. parahaemolyticus. Di wilayah Indonesia yang beriklim tropis, keberadaan dan distribusi $V$. parahaemolyticus berpotensi tinggi sepanjang tahun. Menurut Sullivan \& Neigel (2018), suhu perairan dan salinitas dapat mempengaruhi prevalensi $V$. parahaemolyticus pada lingkungan. Kecuali di tambak Banyuwangi, rata-rata suhu air di ketiga lokasi tambak berada di atas $30^{\circ} \mathrm{C}$. Rendahnya suhu air di Tambak Banyuwangi berkaitan dengan 
Tabel 1. Asal dan sumber sampel

Table 1. Sampel origin and source

\begin{tabular}{lcl}
\hline \multicolumn{1}{c}{ Sumber/Source } & $\begin{array}{c}\text { Jumlah sampel } \\
\text { (unit)/No. of } \\
\text { samples (unit) }\end{array}$ & Asal /Origin \\
\hline Tambak/Ponds & 10 & Rembang dan Jepara/Rembang and Jepara \\
& 10 & Situbondo dan Banyuwangi/Situbondo and Banyuwangi \\
Bahan baku/Raw material & 10 & UPI Jawa Tengah/Fish Processing Unit in Central Java \\
Produk antara//ntermediate & 10 & UPI Jawa Timur/Fish Processing Unit in East Java \\
product $^{1 \text { ) }}$ & 15 & UPI Jawa Tengah/Fish Processing Unit in Central Java \\
& 30 & UPI Jawa Timur/Fish Processing Unit in East Java \\
Produk akhir/Final product ${ }^{2)}$ & 15 & UPI Jawa Tengah/Fish Processing Unit in Central Java \\
\hline Sampel total/Total sample & 10 & UPI Jawa Timur/Fish Processing Unit in East Java \\
\hline
\end{tabular}

Keterangan/Note:

1) Produk antara adalah udang yang diproses dengan cara potong kepala, perendaman, pengupasan dan pencucian/ Intermediate product is shrimp that undergoes of head cutting, soaking, stripping and washing

2) Produk akhir adalah udang dalam bentuk beku atau breaded/Final product is shrimp in frozen or breaded form

waktu pengambilan sampel yang harus menyesuaikan waktu panen udang secara parsial yang dilakukan oleh pemilik tambak saat itu (Tabel 2). yaitu di pagi hari pada pukul 04.00-05.30 WIB.

\section{Isolasi, seleksi dan identifikasi parahaemolyticus}

Hasil identifikasi koloni tipikal $V$. parahaemolyticus pada sampel disajikan pada Tabel 3. Jumlah sampel positif dengan koloni tipikal $V$. parahaemolyticus di UPI Jawa Tengah yang diseleksi dengan CV agar sebanyak 42 sampel dan di UPI Jawa Timur sebanyak
60 sampel, sehingga total sampel dengan koloni tipikal sebanyak 102 sampel. Selanjutnya identifikasi V. parahaemolyticus dari koloni tipikal menghasilkan sampel positif sebanyak 46 sampel (Gambar 1). Beberapa sampel negatif (sampel 5, 7, 10, 14, 16, $17,21,23,24,26,27,28,30,31,39,40,43,47,48$, $49,50,62,66,67,68,69,73,74,75,77,81,83-95$, 97-110) tidak diuji lanjut dengan PCR. Pada penelitian ini, tidak semua sampel memberikan hasil positif ketika dianalisis dengan PCR, sebab tidak semua sampel memiliki gen toxR yang merupakan gen lestari bakteri tersebut (Kim et al., 1999).

Tabel 2. Kondisi lingkungan perairan

Table 2. Water environmental conditions

\begin{tabular}{|c|c|c|c|c|}
\hline $\begin{array}{l}\text { Lokasi tambak/ } \\
\text { Location of ponds }\end{array}$ & $\begin{array}{l}\text { Bulan/ } \\
\text { Month }\end{array}$ & $\begin{array}{c}\text { Suhu perairan/ } \\
\text { Water temperature }\left({ }^{\circ} \mathrm{C}\right)\end{array}$ & $\mathrm{pH} / \mathrm{pH}$ & Keterangan/Note \\
\hline $\begin{array}{l}\text { Rembang (Jawa Tengah)/ } \\
\text { Rembang (Central Java) }\end{array}$ & Mei/May & $32.0-33.0$ & $8.6-8.7$ & 12.30-14.00 WIB/WIT \\
\hline $\begin{array}{l}\text { Jepara (Jawa Tengah)/ } \\
\text { Jepara (Central Java) }\end{array}$ & Mei/May & $31.4-32.0$ & 7.6-7.7 & 14.30-16.00 WIB/WIT \\
\hline $\begin{array}{l}\text { Situbondo (Jawa Timur)/ } \\
\text { Situbondo (East Java) }\end{array}$ & September & $30.0-30.3$ & $8.2-9.6$ & 16.30-18.00 WIB/WIT \\
\hline $\begin{array}{l}\text { Banyuwangi (Jawa Timur)/ } \\
\text { Banyuwangi (East Java) }\end{array}$ & September & $25.0-26.0$ & 7.2-7.4 & 04.00-05.30 WIB/WIT \\
\hline
\end{tabular}

Keterangan/Note:

WIB/WIT : Waktu Indonesia barat/Western Indonesian time

Kondisi optimum pertumbuhan $V$. parahaemolyticus adalah pada suhu perairan $37^{\circ} \mathrm{C}$, pH 7.8-8.6/Optimum condition of $\underline{\mathrm{V}}$. parahaemolyticus growth at water temperature of $37^{\circ} \mathrm{C}, \mathrm{pH}$ 7.8-8.6 (Lake, Hudson \& Cressey, 2003) 


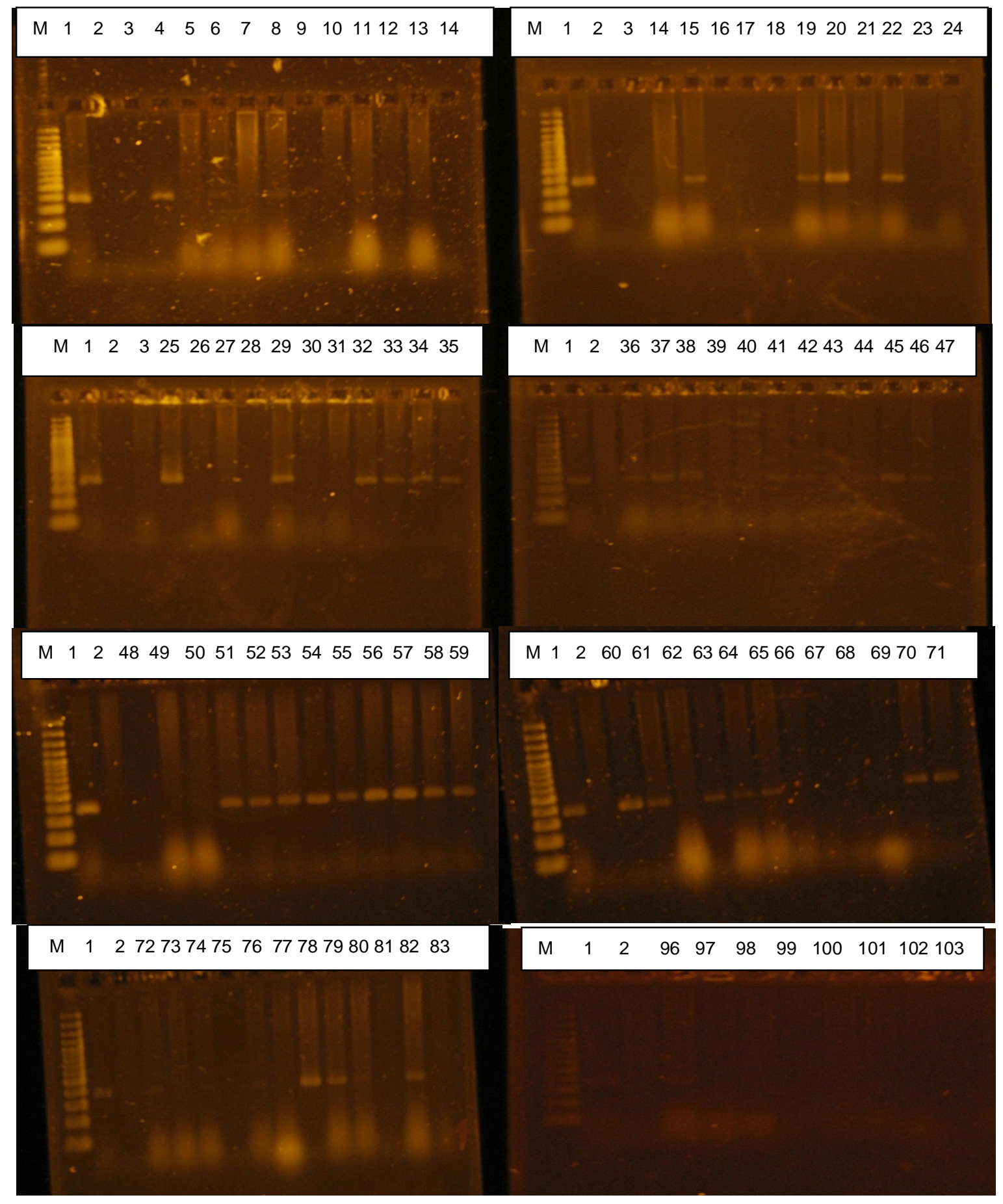

Gambar 1. Deteksi gen toxR pada $V$. parahaemolyticus, M:100 bp marker, 1: Kontrol positif ( $V$. parahaemolyticus), 2: Kontrol negatif (Salmonella sp.), 3: Kontrol negatif (air), 4-102: Sampel (sampel 4, 6, 8, 9, 11, 12, 13, 15,18, 19, 20, 22, 25, 29, 32, 33, 34, 35, 36, 37, 38, 41, 42, 44, 45, $46,51,52,53,54,55,56,57,58,59,60,61,63,64,65,70,71,72,76,78,79,80,82,96$ menunjukkan hasil positif).

Figure 1. toxR gene detection in $\underline{\mathrm{V}}$. parahaemolyticus, M:100 bp ladder, 1: Positive control ( $\underline{\mathrm{V}}$. parahaemolyticus), 2: Negative control (Salmonella sp.), 3: Negative control (water), 4-102: Samples (Sample 4, 6, 8, 9, 11, 12, 13, 15, 18, 19, 20, 22, 25, 29, 32, 33, 34, 35, 36, 37, 38, 41, $42,44,45,46,51,52,53,54,55,56,57,58,59,60,61,63,64,65,70,71,72,76,78,79,80$, 82, 96 showed positive result). 
Tabel 3. Distribusi dan insidensi V. parahaemolyticus pada udang vaname di tambak dan UPI Jawa Tengah dan Jawa Timur

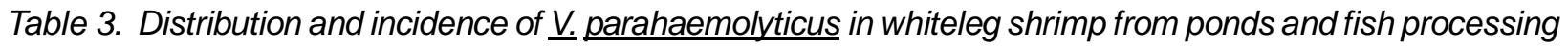
units in Central and East Java.

\begin{tabular}{|c|c|c|c|c|c|c|c|c|c|c|}
\hline \multirow{3}{*}{$\begin{array}{l}\text { Sampel/ } \\
\text { Samples }\end{array}$} & \multicolumn{5}{|c|}{$\begin{array}{c}\text { Tambak dan UPI Jawa Tengah/ } \\
\text { Pond and fish processing unit in } \\
\text { Central Java }\end{array}$} & \multicolumn{5}{|c|}{$\begin{array}{c}\text { Tambak dan UPI Jawa Timur/ } \\
\text { Pond and fish processing unit in } \\
\text { East Java }\end{array}$} \\
\hline & \multirow{2}{*}{$\begin{array}{l}\text { Jumlah } \\
\text { sampel/ } \\
\text { Number of } \\
\text { samples }\end{array}$} & \multicolumn{4}{|c|}{$\begin{array}{l}\text { Jumlah sampel positif/ } \\
\text { No. of positive samples }\end{array}$} & \multirow{2}{*}{$\begin{array}{l}\text { Jumlah } \\
\text { sampel/ } \\
\text { Number of } \\
\text { samples }\end{array}$} & \multicolumn{4}{|c|}{$\begin{array}{l}\text { Jumlah sampel positif/ } \\
\text { No. of positive samples }\end{array}$} \\
\hline & & CV & $\begin{array}{l}\mathrm{Vp} \\
\text { toxR }\end{array}$ & $\begin{array}{l}\text { Vp } \\
\text { tdh }\end{array}$ & Vp trh & & CV & $\begin{array}{l}\mathrm{Vp} \\
\text { toxR }\end{array}$ & $\begin{array}{l}\mathrm{Vp} \\
\text { tdh }\end{array}$ & Vp trh \\
\hline Tambak/Ponds & 10 & 9 & 4 & 1 & 0 & 10 & 10 & 8 & 0 & 0 \\
\hline $\begin{array}{l}\text { Bahan baku/Raw } \\
\text { material }\end{array}$ & 10 & 9 & 4 & 2 & 1 & 10 & 10 & 8 & 0 & 0 \\
\hline $\begin{array}{l}\text { Produk antara/ } \\
\text { Intermediate } \\
\text { product }^{1)}\end{array}$ & 15 & 10 & 7 & 1 & 2 & 30 & 30 & 12 & 0 & 0 \\
\hline $\begin{array}{l}\text { Produk akhir/ } \\
\text { Final product }{ }^{2)}\end{array}$ & 15 & 14 & 2 & 0 & 0 & 10 & 10 & 1 & 0 & 0 \\
\hline $\begin{array}{l}\text { Jumlah total } \\
\text { (positif/Total } \\
\text { number (positive) }\end{array}$ & 50 & 42 & 17 & 4 & 3 & 60 & 60 & 29 & 0 & 0 \\
\hline
\end{tabular}

Keterangan/Note:

1) Produk antara adalah udang yang diproses dengan cara potong kepala, perendaman, pengupasan dan pencucian/ Intermediate product is shrimp that undergoes of head cutting, soaking, stripping and washing

2) Produk akhir adalah udang dalam bentuk beku atau breaded/Final product is shrimp in frozen or breaded form

V. parahaemolyticus juga terdeteksi pada seluruh rantai pasok pengolahan udang, yaitu tambak, bahan baku, produk antara, dan produk akhir (Tabel 3). Prevalensi $V$. parahaemolyticus dari sampel udang tambak Jepara, Rembang, Situbondo hingga Banyuwangi mencapai $12 / 20$ (60\%) dengan perincian 4/10 (40\%) berasal dari tambak Jawa Tengah dan 8/ $10(80 \%)$ dari tambak Jawa Timur. Hal ini sedikit lebih rendah dari penelitian yang dilaporkan sebelumnya, yaitu sebesar 62/103 (60,2\%) (Kusmarwati et al. 2016). Prevalensi $V$. parahaemolyticus pada udang dari tambak Jawa Tengah sebesar 4/10 (40\%), dan dari Jawa Timur sebesar $8 / 10(80 \%)$ dari total sampel tambak. Prevalensi $V$. parahaemolyticus di tambak Jawa Timur relatif lebih tinggi, sedangkan di tambak Jawa Tengah lebih rendah daripada hasil penelitian sebelumnya dimana insidensi $V$. parahaemolyticus pada udang mencapai 29/35 (82,86\%) (Tan et al., 2020) dan pada oyster mencapai $31 / 44$ (70,5\%) (Kang et al., 2017).

V. parahaemolyticus merupakan bakteri alami di perairan laut, tambak dan lingkungan pantai sehingga menyebabkan prevalensi serta penyebarannya di lingkungan tersebut menjadi tinggi. Iklim tropis yang hangat juga mendukung dan lebih disukai $V$. parahaemolyticus (Ceccarelli et al, 2013; Givens, Bowers, DePaola, Hollibaugh, \& Jones, 2014; Schwab, Gastmeier, \& Meyer, 2014).

Dilaporkan bahwa prevalensi $V$. parahaemolyticus pada produk perikanan asal Malaysia sebesar 120/ $140(85,71 \%)$, terdiri dari $32 / 35(91,43 \%)$ pada kerang darah, 31/35 (88,57\%) pada udang, 29/35 (82,86\%) pada tiram dan 28/35 (80\%) pada cumi-cumi (Tan et al., 2020). Insidensi V. parahaemolyticus yang tinggi $(71,4 \%)$ juga dilaporkan oleh Torres Vitela dan Fernández Escartín (1993). Sebaliknya, beberapa peneliti juga melaporkan insidensi $V$. parahaemolyticus yang rendah pada ikan perairan tawar, sebesar 2,6\% (Chan, Woo, Lam, \& French, 1989), 10\% (Jaksic, Uhitil, Petrak, Bazuli, \& Karolyi, 2002) dan 13,83\% (Das, Manna, Sarkar, \& Batabyal, 2009).

Menurut Nelapati dan Khrisnaiah (2010) persentase hasil sampel positif yang diperoleh dengan metode PCR lebih akurat dari metode kultur. Dari 105 
sampel (ikan air tawar, ikan laut dan daging domba) metode kultur dapat mendeteksi $28,6 \%$ sampel positif, sedangkan PCR dapat mendeteksi 37,1\% sampel positif V. parahaemolyticus. Raghunath, Acharya, Bhanumathi, Karunasagar, dan Karunasagar (2008) melaporkan tingginya insidensi $\mathrm{V}$. parahaemolyticus pada ikan laut dengan metode kultur sebanyak 55,5\% dan dengan PCR 66,6\%. Disebutkan bahwa suhu perairan dan salinitas dapat mempengaruhi bahkan memicu pertumbuhan $V$. parahaemolyticusyang bersifat patogen (Sullivan dan Neigel, 2018; Yu et al., 2015)

Secara keseluruhan, keberadaan $V$. parahaemolyticus dalam penelitian ini cukup rendah, kemungkinan selain disebabkan oleh keberadaannya di lingkungan yang rendah, juga karena sifatnya yang lebih sensitif sehingga mudah berubah menjadi fase viable but nonculturable (VNC). Pada fase ini bakteri berada pada fase dorman yang hanya mampu melakukan proses metabolism namun tidak mampu menggandakan diri sehingga pada fase ini relatif sulit untuk diisolasi (Hackney \& Dicharry, 1988; Nishibuchi \& Kaper, 1995; Raghunath, Karunasagar, \& Karunasagar, 2009; Shirai et al., 1990). Oleh karena itu prevalensi bakteri $V$. parahaemolyticus patogen yang rendah dari lingkungan bukan disebabkan oleh metode deteksi yang tidak akurat.

Berdasarkan hasil analisis terhadap sampel positif V. parahaemolyticus pada udang dari Jawa Tengah, telah teridentifikasi sampel positif tdh sebanyak 4/17 $(25,53 \%)$ dan positif trh $3 / 17(17,65 \%)$ yang berasal dari salah satu UPI di Jawa Tengah (Tabel 3). Berdasarkan pengamatan di lapangan, udang vaname yang digunakan sebagai sampel di UPI ini dilakukan proses sortasi terlebih dahulu di sekitar lokasi tambak milik pemasok. Sedangkan ketiga UPI yang lain langsung membawa udang hasil panen tambak ke UPI masing-masing tanpa melakukan proses sortasi terlebih dahulu. Proses sortasi udang dilakukan oleh 5-6 orang petani tambak sebelum udang tersebut ditransportasikan ke UPI. Kondisi fasilitas sortasi jauh dari kondisi sanitasi yang baik (tidak dilengkapi air bersih untuk mencuci udang dan tidak diterapkan sistem rantai dingin) sehingga berpeluang meningkatkan insidensi V. parahaemolyticus patogen.

Insidensi $V$. parahaemolyticus patogen yang cukup rendah pada penelitian ini sejalan dengan Yingkajorn et al. (2014) dan Letchumanan, Chan, dan Learn-Han. (2015) bahwa insidensi $V$. parahaemolyticus patogen udang vaname sekitar 0/185 (0\%) hingga 14/88 $(15,9 \%)$ untuk sampel positif tdh dan sekitar 4/88 (4,6\%) hingga 19/185 (10\%) untuk sampel positif trh. Zarei, Borujeni, Jamnejad, dan Khezrzadeh (2012) menyebutkan terdapat 2 dari 75 (2,67\%) sampel udang terdeteksi positif tdh yang dikumpulkan dari outlet ritel di bagian Barat Daya Iran pada musim panas. Laporan lain dari Iran menyebutkan prevalensi $V$. parahaemolyticus tdh dan trh pada udang sebesar 1,7\% dan 0,7\% (Rahimi, Ameri, Doosti, \& Gholampour, 2010). Menurut Okuda et al. (1997) dan Saito et al. (2015) isolat positif tdh jarang terdeteksi di sampel lingkungan sehingga kasusnya menjadi rendah. Dilaporkan bahwa mayoritas $V$. parahaemolyticus yang membawa gen $t d h$ dan trh terkait dengan kasus klinis yang terjadi di dunia, khususnya dikaitkan dengan fenomena Kanagawa positif yang menyebabkan penyakit gastroenteritis, namun aktivitas hemolisin pada tdh dan trh tidak sepenuhnya menjadi penyebab patogenisitasnya, sebab pernah ditemukan strain klinis yang tidak mengandung gen tdh ataupun trh (Lynch et al., 2005; Nishibuchi \& Kaper, 1995; Pazhani et al., 2014).

Konsentrasi $V$. parahaemolyticus toxR pada udang UPI sebagai produk antara dan produk akhir seperti disajikan pada Tabel 4. Selama masa tunggu, lamanya waktu dan suhu udang sebelum diproses di UPI mempengaruhi konsentrasi bakteri. Pada masa ini udang yang ditempatkan dalam fiber diletakkan di luar ruangan dengan suhu udara $>30^{\circ} \mathrm{C}$ sampai menunggu waktu proses di UPI. Dalam hal ini masa tunggu udang untuk setiap UPI berbeda-beda mengikuti permintaan pembeli/negara pengimpor, yakni berkisar antara 1822 jam. Pada tahap ini, konsentrasi $V$. parahaemolyticus cukup tinggi mencapai 1.100 MPN/ g yang mengindikasikan adanya potensi bahaya pada produk. Kondisi tersebut memungkinkan berdampak pada tingkat keamanan udang pada rantai pasok berikutnya di UPI, seperti pada tahap pengolahan dan produk akhir.

Jumlah produk antara udang dari Jawa Tengah dan Jawa Timur sebanyak 15 dan 30 sampel (Tabel 4) dengan prevalensi toxR dari masing-masing lokasi sebesar $7 / 15$ (46,67\%) dan 12/30 (40\%). Di UPI Jawa Tengah, dari tujuh sampel positif gen toxR, ditemukan sampel positif $t d h$ sebanyak 1/7 (14,29\%) dan trh 2/7 $(28,57 \%)$, sedangkan dari UPI Jawa Timur, dari 12 sampel positif $V$. parahaemolyticus tidak ditemukan sampel positif tdh maupun trh. Meskipun hanya ditemukan satu sampel positif tdhdan dua sampel positif trh di Jawa Tengah, namun tetap berpeluang menimbulkan risiko.

Sementara itu jumlah produk akhir udang dari Jawa Tengah dan Jawa Timur masing-masing sebanyak 15 dan 10 sampel dengan prevalensi tox $R$ masing-masing lokasi sebesar 2/15 (13,33\%) dan 1/10 (10\%). Namun dari ketiga sampel positif gen toxR tersebut tidak ditemukan sampel yang mengandung gen $t d h$ maupun trh sebagaimana disajikan pada Tabel 4. 
Tabel 4. APM dan prevalensi V. parahaemolyticus pada udang vaname sebagai produk antara dan produk akhir di UPI

Tabel 4. MPN and prevalence of $\underline{\text {. }}$ parahaemolyticus in whiteleg shrimp as intermediate and final products in fish processing unit

\begin{tabular}{|c|c|c|c|c|c|c|}
\hline \multirow[b]{2}{*}{ Asal/Origin } & \multirow{2}{*}{$\begin{array}{c}\text { Produk antara dan } \\
\text { produk akhir/ } \\
\text { Intemediate product and } \\
\text { final product }\end{array}$} & \multirow{2}{*}{$\begin{array}{c}\text { Jumlah } \\
\text { sampel } \\
\text { yang diuji/ } \\
\text { No. of } \\
\text { samples } \\
\text { examined }\end{array}$} & \multirow{2}{*}{$\begin{array}{l}\mathrm{APM} / \mathrm{g} / \\
\mathrm{MPN} / \mathrm{g}\end{array}$} & \multicolumn{3}{|c|}{$\begin{array}{l}\text { Jumlah sampel positif/ } \\
\text { No. of positive samples }\end{array}$} \\
\hline & & & & $V p$ tox $R$ & $V p t d h+$ & Vp trh+ \\
\hline \multicolumn{7}{|c|}{ Produk antara/Intemediate product } \\
\hline Rembang & $\begin{array}{l}\text { Udang kupas/ } \\
\text { Peeled shrimp }\end{array}$ & 5 & $3.6-4.3$ & 4 & 1 & 2 \\
\hline \multirow[t]{2}{*}{ Jepara } & $\begin{array}{l}\text { Udang potong kepala/ } \\
\text { Head-off shrimp }\end{array}$ & 5 & $36-1100$ & 2 & 0 & 0 \\
\hline & $\begin{array}{l}\text { Udang kupas/ } \\
\text { Peeled shrimp }\end{array}$ & 5 & $>1100$ & 1 & 0 & 0 \\
\hline \multicolumn{2}{|c|}{ Jumlah sampel/Total samples } & & & 7 & 1 & 2 \\
\hline \multicolumn{2}{|c|}{$\begin{array}{l}\text { Prevalensi V. parahaemolyticus/Prevalence } \\
\text { of V. parahaemolyticus (\%) }\end{array}$} & 15 & & $\begin{array}{c}7 / 15 \\
(46.67)\end{array}$ & $\begin{array}{c}1 / 7 \\
(14.29)\end{array}$ & $\begin{array}{c}2 / 7 \\
(28.57) \\
\end{array}$ \\
\hline Situbondo & $\begin{array}{l}\text { Udang potong kepala/ } \\
\text { Head-off shrimp }\end{array}$ & 5 & Nov-93 & 3 & 0 & 0 \\
\hline \multirow{5}{*}{ Banyuwangi } & $\begin{array}{l}\text { Udang soaking/ } \\
\text { Soaked shrimp }\end{array}$ & 5 & $27-460$ & 4 & 0 & 0 \\
\hline & $\begin{array}{l}\text { Udang setelah cuci/ } \\
\text { Washed shrimp }\end{array}$ & 5 & $7.2-120$ & 4 & 0 & 0 \\
\hline & $\begin{array}{l}\text { Udang potong kepala/ } \\
\text { Head-off shrimp }\end{array}$ & 5 & 9.2 & 1 & 0 & 0 \\
\hline & $\begin{array}{l}\text { Udang soaking/ } \\
\text { Soaked shrimp }\end{array}$ & 5 & $<3-15$ & 0 & 0 & 0 \\
\hline & $\begin{array}{l}\text { Udang kupas/ } \\
\text { Peeled shrimp }\end{array}$ & 5 & $<3-15$ & 0 & 0 & 0 \\
\hline \multicolumn{2}{|c|}{ Jumlah sampel/Total samples } & & & 12 & 0 & 0 \\
\hline \multicolumn{2}{|c|}{$\begin{array}{l}\text { Prevalensi V. parahaemolyticus/Prevalence } \\
\text { of } V \text {. parahaemolyticus (\%) }\end{array}$} & 30 & & $\begin{array}{r}12 / 30 \\
(40.00)\end{array}$ & 0 & 0 \\
\hline \multicolumn{7}{|c|}{ Produk akhir/Final product } \\
\hline Rembang & $\begin{array}{l}\text { Udang beku \& breaded/ } \\
\text { Frozen \& breaded shrimp }\end{array}$ & 10 & $35-74$ & 2 & 0 & 0 \\
\hline Jepara & $\begin{array}{l}\text { Udang beku/ } \\
\text { Frozen shrimp }\end{array}$ & 5 & 0 & 0 & 0 & 0 \\
\hline \multicolumn{2}{|c|}{ Jumlah sampel/Total samples } & & & 2 & 0 & 0 \\
\hline \multicolumn{2}{|c|}{$\begin{array}{l}\text { Prevalensi V. parahaemolyticus/Prevalence } \\
\text { of V. parahaemolyticus (\%) }\end{array}$} & 15 & & $\begin{array}{c}2 / 15 \\
(13.33)\end{array}$ & 0 & 0 \\
\hline Situbondo & $\begin{array}{l}\text { Udang beku/ } \\
\text { Frozen shrimp }\end{array}$ & 5 & 11 & 1 & 0 & 0 \\
\hline Banyuwangi & $\begin{array}{l}\text { Udang beku/ } \\
\text { Frozen shrimp }\end{array}$ & 5 & $3.6-15$ & 0 & 0 & 0 \\
\hline \multicolumn{2}{|c|}{ Jumlah sampel/Total samples } & & & 1 & 0 & 0 \\
\hline \multicolumn{2}{|c|}{$\begin{array}{l}\text { Prevalensi V. parahaemolyticus/Prevalence } \\
\text { of V. parahaemolyticus (\%) }\end{array}$} & 10 & & $\begin{array}{c}1 / 10 \\
(10.00)\end{array}$ & 0 & 0 \\
\hline
\end{tabular}




\section{KESIMPULAN}

V. parahaemolyticus terdeteksi pada sampel udang vaname asal UPI Jawa Tengah sebesar 17 sampel positif dari 50 sampel yang duji (34\%). Sebanyak empat sampel dari sampel positif ini mengandung gen tdh dan tiga sampel positif mengandung gen trh. Sedangkan prevalensi $V$. parahaemolyticus total di UPI Jawa Timur adalah 29 sampel positif $V$. parahaemolyticus dari 60 sampel $(48,33 \%)$, dan tidak mengandung $V$. parahaemolyticus patogen. $V$. parahaemolyticus patogenik tdh dan trhyang terdeteksi pada UPI Jawa Tengah selama tahap penerimaan bahan baku dan proses pengolahan memperlihatkan adanya peluang risiko bagi kesehatan masyarakat. Oleh karena itu diperlukan pemantauan secara intensif pada kedua tahap tersebut.

\section{UCAPAN TERIMAKASIH}

Penelitian ini mendapat dukungan dari kegiatan riset Balai Besar Riset Pengolahan Produk dan Bioteknologi Kelautan dan Perikanan pada tahun 2016. Ucapan terimakasih diberikan kepada Prof. Dr. Harsi Kusumaningrum, MSc atas supervisinya, Kepala BKIPM Semarang dan Banyuwangi, pimpinan perusahaan udang/UPI di Jawa Tengah dan Jawa Timur. Ucapan terimakasih juga disampaikan kepada Novalia Rachmawati, M. Sc atas supervisi penulisan naskah, Gunawan, S.TP, Anggaraeni Musvitawati, S.TP dan Nabilah atas bantuan dan kontribusinya untuk terlaksananya penelitian ini.

\section{DAFTAR PUSTAKA}

Amizar, R. (2011). Karakterisasi molekuler dari V. parahaemolyticus dan $V$. cholerae yang diisolasi dari produk perikanan (udang, kerang dan kepiting) asal kota Padang, Sumatera Barat dan Muara Angke, Jakarta Utara. Artikel. Program Pasca Sarjana Universitas Andalas, Padang. 24p.

Broberg, C. A., Calder, T. J., \& Orth, K. (2011). Review Vibrio parahaemolyticus cell biology and pathogenicity determinants. Microbes and Infection, 13, 992-10.

Ceccarelli, D., Hasan, N, A., Huq, A., \& Colwell, R. R. (2013). Distribution and dynamics of epidemic and pandemic Vibrio parahaemolyticus virulence factors. Frontiers in Cellular and Infection Microbiology. 3, Article 97.

Centre for Health Protection. (2010). Scientific Committee on Enteric Infections and Foodborne Diseases Food Poisoning Associated with V. parahaemolyticus in Hong Kong-Current Situation and Recommendations.Department of Health for Disease Prevention and Control.15 p.

Chan, K. Y., Woo. M. L., Lam, L. Y., \& French, G. L. (1989). Vibrio parahaemolyticus and other halophilic vibrios associated with seafood in Hong Kong. J. Appl. Microbiol., 66, 57-64.

Chen, A. J., Hasan, A. N., \& Huq, A. (2017). Characterization of pathogenic Vibrio parahaemolyticus from the Chesapeake Bay, Maryland. Frontiers in microbiology, 8, 2460. doi : 10.3389/fmicb.2017.02460.

Das, B., Manna, S.K., Sarkar, P \& Batabyal, K. (2009). Occurrence of Vibrio parahaemolyticus in different finfish and shellfish species. J. Food Safety, 29, 118125.

Direktorat Jenderal Pengolahan dan Pemasaran Hasil Perikanan (Ditjen P2HP-KKP). (2010). Rekapitulasi penolakan kasus RAS 2005-2009. Kementerian Kelautan dan Perikanan.

Elhadi, N. (2012). Occurence of potentially human pathogenic Vibrio species in the coastal water of the eastern province of Saudi Arabia. Research Journal of Microbiology, 8, 1-12. doi: 10.3923/jm.2013.1.12

Givens, C. E., Bowers, J. C., DePaola, A., Hollibaugh, J. T., Jones, J. I. (2014). Occurrence and distribution of Vibrio vulnificus and Vibrio parahaemolyticus potential roles for fish, oyster, sediment and water. Lett. Appl. Microbiol. 58(6), 503-510. doi: org/10.1111/ lam.12226.

Hackney, C. R., \& Dicharry, A. (1988). Seafoodborne bacterial pathogens of marine origin. Food Technology, 42, 104-109.

Jaksic, S., Uhitil, S., Petrak, T., Bazuli, D. \& Karolyi, L.G. (2002). Occurrence of Vibrio spp. in sea fish, shrimps and bivalve molluscs from Adriatic Sea. Food Control, 13, 491-493.

Kang, C. H., Shin, Y., Jang, S. C., Yu, H., S., Kim, S. K., An, S., Park, K., \& So, J. S. (2017). Characterization of Vibrio parahaemolyticus isolated from oysters in Korea: Resistance to various antibiotics and prevalence of virulence genes. Marine Pollution Bulletin, 118(1-2), 261-266. doi: 10.1016/ j.marpolbul.2017.02.070.

Katadata KKP. (2016). Indonesia Raja Udang ASEAN. Retrieved from http://www.m.katadata.co.id/infografik/ 2016/03/30/indonesia (Diakses tanggal 19 Juli 2016).

Kim, Y. B., Okuda, J., Matsumoto, C., Takahashi, N., Hashimoto, S.,\& Nishibuchi, M. (1999). Identification of $V$. parahaemolyticus strains at the species level by PCR targeted to the tox $R$ gene. Journal of Clinical Microbiology, 37, 1173-1177.

Kraa, E. (1995). Surveillance and epidemiology of foodborne illness in New South Wales, Australia. Food Australia. 47, 418-423.

Kusmarwati, A., Hermana, I., Yennie, Y. \& Wibowo, S. (2016). Keberadaan Vibrio parahaemolyticus Patogenik pada Udang Tambak yang Berasal dari Pantai Utara Jawa. Jurnal Pascapanenn dan Bioteknologi Kelautan dan Perikanan, 11(1), 41-54.

Lake, R., Hudson, A., \& Cressey, P. (2003). Risk profile: Vibrio parahaemolyticus in seafood. Institute of Environmental Science and Research Ltd, Christchurch, New Zealand. $47 \mathrm{p}$. 
Lesmana, M., Subekti, D., Simanjuntak, C. H., Tjaniadi P., Campbell, J. R., \& Oyofo, B. A. (2001). Vibrio parahaemolyticus associated with cholera-like diarrhea among patients in North Jakarta, Indonesia. Diagn Microbiol Infect Dis, 39(2), 71-5.

Lesmana, M., Subekti, D. S., Tjaniadi, P., Simanjuntak, C. H., Punjabi, N. H., Campbell, J. R., \& Oyofo, B. A. (2002). Spectrum of Vibrio species associated with acute diarrhea in North Jakarta, Indonesia. Diagn Microbiol Infect Dis. 43(2), 91-7.

Letchumanan, V., Chan, K. G., \& Lee, L. H. (2014). Vibrio parahaemolyticus: A review on the pathogenesis, prevalence, and advance molecular identification techniques. Frontiers in Microbiology. Frontiers Media S.A. https://doi.org/10.3389/fmicb.2014.00705

Lynch, T., Livingstone, S., Buenaventura, E., Lutter, E., Fedwick, J., Buret, A. G., ... DeVinney, R. (2005). Vibrio parahaemolyticus disruption of epithelial cell tight junctions occurs independently of toxin production. Infection and Immunity, 73(3), 1275-1283. https:// doi.org/10.1128/IAI.73.3.1275-1283.2005

Matsumoto, C., Okuda, J., Ishibashi, M., Iwanaga, M., Garg, P., Rammamurthy, T., ... Nishibuchi, M. (2000). Pandemic spread of an O3:K6 clone of Vibrio parahaemolyticus and emergence of related strains evidenced by arbitrarily primed PCR and toxRS sequence analyses. Journal of Clinical Microbiology, 38(2), 578-585. https://doi.org/10.1128/jcm.38.2.578585.2000

Mo, Y. (2017). 3 Jenis Udang Komoditas Ekspor Terunggul Indonesia. Retrieved from https:// www.isw.co.id/single-post/2017/02/04/3-JenisUdang-Komoditas-Ekspor-Terunggul-Indonesia. (Diakses tanggal 18 September 2019).

Nelapati, S., \& Krishnaiah, N. (2010). Detection of total and pathogenic $V$. parahaemolyticus by polymerase chain reaction using tox $R, t d h$ and trh genes. Veterinary World, 3(6), 268-271.

Nishibuchi, M., \& Kaper, J. B. (1995). Thermostable direct hemolysin gene of $V$. parahaemolyticus: a virulence gene acquired by a marine bacterium. Infect Immun, 63(6), 2093-2099.

Okuda, J., Ishibashi, M., Hayakawa, E., Nishino, T., Takeda, Y., Mukhopadhyay, A. K., ... Nishibuchi, M. (1997). Emergence of a unique O3:K6 clone of Vibrio parahaemolyticus in Calcutta, India, and isolation of strains from the same clonal group from Southeast Asian travelers arriving in Japan. Journal of Clinical Microbiology, 35(12), 3150-3155. https://doi.org/ 10.1128/jcm.35.12.3150-3155.1997

Pazhani, G. P., Bhowmik, S. K., Ghosh, S., Guin, S., Dutta, S., Rajendran, K., (2014). Trends in the epidemiology of pandemic and non-pandemic strains of Vibrio parahaemolyticus isolated from diarrheal patients in Kolkata, India. PLoS Negl. Trop. Dis. 8,2815. doi: 10.1371/journal.pntd.0002815.

Raghunath, P. (2015). Roles of thermostable direct hemolysin (TDH) and TDH-related hemolysin (TRH) in Vibrio parahaemolyticus. Frontiers in Cellular and Infection Microbiology, 5. Article 805.
Raghunath, P., Acharya, S., Bhanumathi, A., Karunasagar, I., \& Karunasagar, I. (2008). Detection of molecular characterization of Vibrio parahaemolyticus isolated from seafood harvested along the southwest coast of India. Food Microbiol, 25, 824-830.

Raghunath, P., Karunasagar, I., \& Karunasagar, I. (2009). Improved isolation and detection of pathogenic Vibrio parahaemolyticus from seafood using a new enrichment broth: Short Communication. Int. J. Food Microbiol, 129, 200-203.

Rahimi, E., Ameri, M., Doosti, A., \& Gholampour, A. R. (2010). Occurrence of toxigenic Vibrio parahaemolyticus strains in shrimp in Iran. Foodborne pathogens and disease, 7 (9), 1107-1111.

Rapid Alert System for Food and Feed. (2019). RASFF Portal. Notifications list. Retrieved from https:// webgate.ec.europa.eu/rasffwindow/portal/ ? event $=$ SearchByKeyword\&NewSearch $=1 \&$ Keywords=vibrio\%20 parahaemolyticus. (Diakses tanggal 18 September 2019).

Saito, S., Iwade, Y., Tokuoka, E., Nishio, T., Otomo, Y., Araki, E., ... Hara-Kudo, Y. (2015). Epidemiological evidence of lesser role of thermostable direct hemolysin $(T D H)$ - Related hemolysin $(T R H)$ than TDH on Vibrio parahaemolyticus pathogenicity. Foodborne Pathogens and Disease, 12(2), 131-138. https://doi.org/10.1089/fpd.2014.1810

Sani, N. A., Ariyawansa, S., Babji, A. S., \& Hashim, J. K. (2013). The risk assessment of Vibrio parahaemolyticus in cooked black tiger shrimps (Penaeus monodon) in Malaysia. Food Control, 31, 546552.

Schwab, F., Gastmeier, P., \& Meyer, E., (2014). The warmer the weather, the more Gram negative bacteria impact of temperature on clinical isolates in intensif care units. PLoS One. 9(3), 91-105. doi: https://doi.org/ 10.1371/journal.pone.0091105.

Shirai, H., Ito, H., Hirayama,T., Nakamoto, Y., Nakabayashi, N., \& Kumagai, K. (1990). Molecular epidemiologic evidence for association of thermostable direct hemolysin (TDH) and TDHrelated hemolysin of Vibrio parahaemolyticus with gastroenteritis. Infect. Immun. 58, 3568-3573.

Sullivan, T. J., \& Neigel, J. E. (2018). Effects of temperature and salinity on prevalence and intensity of infection of blue crabs, Callinectes sapidus, by Vibrio cholerae, V. parahaemolyticus, and $V$. vulnificus in Louisiana. Journal of Invertebrate Pathology, 1-38. doi: https://doi.org/10.1016/ j.jip.2017.11.004

Sunorita, M. \& Tjarsono, I. (2014). Kebijakan Hambatan Non Tarif Di Pasar Uni Eropa Terhadap Ekspor Komoditas Udang Indonesia. Jurnal Transnasional, 6(1).

Tada, J., Ohashi, T., Nishimura, N., Shirasaki, Y., Ozaki, H., Fukushima, S., ... Takeda, Y. (1992). Detection of the thermostable direct hemolysin gene (tdh) and the thermostable direct hemolysin-related hemolysin gene (trh) of Vibrio parahaemolyticus by polymerase chain reaction. Molecular and Cellular Probes, 6(6), 
477-487.https://doi.org/10.1016/08908508(92)90044-X

Tan, C. W., Rukayadi, Y., Hasan, H., Thung, T. Y., Lee, E., Rollon, W. D., ... Radu, S. (2020). Prevalence and antibiotic resistance patterns of Vibrio parahaemolyticus isolated from different types of seafood in Selangor, Malaysia. Saudi Journal of Biological Sciences, 27, 1602-1608. doi.org/10.1016/ j.sjbs.2020.01.002.

Tarr, C. L., Patel, J. S., Puhr, N. D., Sowers, E. G., Bopp, C. A., \& Strockbine, N. A. (2007). Identification of Vibrio isolates by a multiplex PCR assay and rpoB sequence determination. Journal of Clinical Microbiology, 45(1), 134-140. https:// doi.org/10.1128/JCM.01544-06

US Food and Drug Administration (USFDA). (2015). BAM Appendix 2 : Most Probable Number from serial dilution. Retrieved from http://www.fda.gov/food/ foodscienceresearch/Laboratory Methods/ ucm109656.htm. (Diakses tanggal 10 Oktober 2016).

Torres Vitela, M. R., \& Fernández Escartín, E. (1993). Incidence of Vibrio parahaemolyticus in raw fish, oysters, and shrimp. Revista Latinoamericana de Microbiología, 35(3), 267-272.

Wang, R., Zhong, Y., Gu, X., Yuan, J., Saeed, A. F, \& Wang, S. (2015). The pathogenesis, detection, and prevention of Vibrio parahaemolyticus. Frontiers in Microbiology, 6(144), 1-13.

Widowati, R. (2008). Keberadaan bakteri Vibrio parahaemolyticus pada udang yang dijual di rumah makan kawasan Pantai Pangandaran. Vis Vitalis, 1(1), 9-14.
Yennie, Y., Hariyadi, R. D., \& Poernomo, A. (2015). Prevalensi Gen tdh dan trh Vibrio parahaemolyticus pada Udang Vaname Di Wilayah Indramayu, Jawa Barat. Jurnal Pascapanen Dan Bioteknologi Kelautan Dan Perikanan, 10(1), 61. https://doi.org/10.15578/ jpbkp.v10i1.245

Yingkajorn, M., Mitraparp-Arthorn, P., Nuanualsuwan, S., Poomwised, R., Kongchuay, N., Khamhaeng, N., \& Vuddhakul, V. (2014). Prevalence and quantification of pathogenic Vibrio parahaemolyticus during shrimp culture in Thailand. Diseases of Aquatic Organisms, 112(2), 103-111. https://doi.org/10.3354/dao02800

Yu, Q., Niu, M., Yu, M., Liu, Y., Wang, D., \& Shi, X. (2015). Prevalence and Antimicrobial Susceptibility of $V$. parahaemolyticus Isolated from Retail Shellfish in Shanghai. Food Control, 60, 263-268. doi.org/ 10.1016/j.foodcont.2015.08.005

Zarei, M., Borujeni, M. P., Jamnejad, A., \& Khezrzadeh, M. (2012). Seasonal prevalence of Vibrio species in retail shrimps with an emphasis on Vibrio parahaemolyticus. Food Control, 25(1), 107-109. https://doi.org/10.1016/j.foodcont.2011.10.024

Zhang, L., \& Orth, K. (2013). Virulence determinants for Vibrio parahaemolyticus infection. Curr. Opin. Microbiol, 16, 70-77. doi: 10.1016/j.mib.2013.02.002

Zulkifli, Y., Alitheen, N. B., Son, R., Yeap, S. K., Lesley, M. B., \& Raha, A. R. (2009). Identification of $V$. Parahaemolyticus isolates by PCR targeted to the tox $R$ gene and detection of virulence genes. International Food Research Journal, 16, 289-296 